\title{
Genome-wide analysis of MicroRNA- messenger RNA interactome in ex-vivo gill filaments, Anguilla japonica
}

\author{
Hoi Man Ng${ }^{1 \dagger}$, Jeff Cheuk Hin Ho ${ }^{1 \dagger}$, Wenyan Nong ${ }^{2}$, Jerome Ho Lam Hui ${ }^{2}$, Keng Po Lai ${ }^{3^{*}}$ and
} Chris Kong Chu Wong ${ }^{1 *}$

\begin{abstract}
Background: Gills of euryhaline fishes possess great physiological and structural plasticity to adapt to large changes in external osmolality and to participate in ion uptake/excretion, which is essential for the re-establishment of fluid and electrolyte homeostasis. The osmoregulatory plasticity of gills provides an excellent model to study the role of microRNAs (miRs) in adaptive osmotic responses. The present study is to characterize an ex-vivo gill filament culture and using omics approach, to decipher the interaction between tonicity-responsive miRs and gene targets, in orchestrating the osmotic stress-induced responses.
\end{abstract}

Results: Ex-vivo gill filament culture was exposed to Leibovitz's L-15 medium (300 mOsmol $\mathrm{I}^{-1}$ ) or the medium with an adjusted osmolality of $600 \mathrm{mOsmol} \mathrm{I}^{-1}$ for 4, 8 and $24 \mathrm{~h}$. Hypertonic responsive genes, including osmotic stress transcriptional factor, $\mathrm{Na}^{+} / \mathrm{Cl}^{-}$-taurine transporter, $\mathrm{Na}^{+} / \mathrm{H}^{+}$exchange regulatory cofactor, cystic fibrosis transmembrane regulator, inward rectifying $\mathrm{K}^{+}$channel, $\mathrm{Na}^{+} / \mathrm{K}^{+}$-ATPase, and calcium-transporting ATPase were significantly upregulated, while the hypo-osmotic gene, V-type proton ATPase was downregulated. The data illustrated that the ex-vivo gill filament culture exhibited distinctive responses to hyperosmotic challenge. In the hyperosmotic treatment, four key factors (i.e. drosha RNase III endonuclease, exportin-5, dicer ribonuclease III and argonaute-2) involved in miR biogenesis were dysregulated $(P<0.05)$. Transcriptome and miR-sequencing of gill filament samples at 4 and $8 \mathrm{~h}$ were conducted and two downregulated miRs, miR-29b-3p and miR-200b-3p were identified. An inhibition of miR-29b-3p and miR-200b-3p in primary gill cell culture led to an upregulation of 100 and 93 gene transcripts, respectively. Commonly upregulated gene transcripts from the hyperosmotic experiments and miR-inhibition studies, were overlaid, in which two miR-29b-3p target-genes [Krueppel-like factor 4 (klf4), Homeobox protein Meis2] and one miR-200b-3p target-gene (slc17a5) were identified. Integrated miR-mRNA-omics analysis revealed the specific binding of miR-29b-3p on Klf4 and miR-200b-3p on slc17a5. The target-genes are known to regulate differentiation of gill ionocytes and cellular osmolality.

(Continued on next page)

\footnotetext{
* Correspondence: kengplai@cityu.edu.hk; ckcwong@hkbu.edu.hk

${ }^{\dagger} \mathrm{Hoi} \mathrm{Man} \mathrm{Ng}$ and Jeff Cheuk Hin Ho contributed equally to this work.

${ }^{3}$ Guanxi Key Laboratory of Tumor Immunology and Microenvironmental

Regulation, Guilin Medical University, Huan Cheng North 2nd Road 109,

Guilin 541004, People's Republic of China

${ }^{1}$ Croucher Institute for Environmental Sciences, Department of Biology, Hong

Kong Baptist University, Kowloon Tong, HKSAR, Hong Kong

Full list of author information is available at the end of the article
}

(c) The Author(s). 2020 Open Access This article is licensed under a Creative Commons Attribution 4.0 International License, which permits use, sharing, adaptation, distribution and reproduction in any medium or format, as long as you give appropriate credit to the original author(s) and the source, provide a link to the Creative Commons licence, and indicate if changes were made. The images or other third party material in this article are included in the article's Creative Commons licence, unless indicated otherwise in a credit line to the material. If material is not included in the article's Creative Commons licence and your intended use is not permitted by statutory regulation or exceeds the permitted use, you will need to obtain permission directly from the copyright holder. To view a copy of this licence, visit http://creativecommons.org/licenses/by/4.0/ The Creative Commons Public Domain Dedication waiver (http://creativecommons.org/publicdomain/zero/1.0/) applies to the data made available in this article, unless otherwise stated in a credit line to the data. 
(Continued from previous page)

Conclusions: In this study, we have characterized the hypo-osmoregulatory responses and unraveled the modulation of miR-biogenesis factors/the dysregulation of miRs, using ex-vivo gill filament culture. MicroRNAmessenger RNA interactome analysis of miR-29b-3p and miR-200b-3p revealed the gene targets are essential for osmotic stress responses.

Keywords: Fish gill osmoregulation, Hyperosmotic stress, Japanese eel, Transcriptome, microRNA inhibitors

\section{Background}

The catadromous fish Japanese eels have a complex life cycle in freshwater and seawater environments. The fish is euryhaline and actively engage physiological responses to oppose osmotic perturbations to stabilize body osmolality. Fish gills therefore possess great structural and functional plasticity in response to variations of water osmolality, to support the process of fluid and electrolyte homeostasis $[1,2]$. In response to osmotic stress, a distinct suite of modifications in gill epithelia is activated for functional adaptation, which involves cell proliferation and differentiation, changes in the activities, expressions and trafficking of different ion transporters/ channels $[3,4]$. In the past decades, considerable numbers of reports identified the underlying molecular and physiological factors associated with ion-osmoregulatory functions of gills. In recent, advances in the understanding of small non-coding RNAs such as microRNAs (miRs) on regulatory circuit in physiological and pathophysiological functions shed light on roles of miRs in osmotic stress responses.

In mammals, the involvement of miRs in fluid and electrolyte transport has become apparent. A number of studies have illustrated the implications of miRs in ion transport functions. For instances, a direct regulatory role of miR-9 in the expression of large-conductance calcium and voltage-activated potassium channels in neuronal ion transport in alcohol tolerance phenomenon in an adult rat model was identified [5]. The involvement of miR-133a and miR-133b in primary culture of canine cardiomyocytes [6] and miR-1 [7] on potassium channels for cardiac arrhythmias in human samples and rat models were demonstrated. Moreover, indirect regulatory roles of miRs (i.e. miR-155, miR124 \& miR-135a) on ion transport were reported via their inhibitory actions on receptors of electrolyte-regulated hormones, angiotensin-I receptor or mineralocorticoid receptor, in screening samples of patients with hypertension $[8,9]$. The expression level of the with-no-lysine kinase (wnk1, a regulator of electrolyte homeostasis) in mouse nephrons, was found to be regulated by miR-192. Its expression was modulated by physiological stimuli (i.e. aldosterone or salts loading) [10]. In renal medullary epithelial mIMCD3 cells, tonicity was also identified as a stimulus to regulate miR-200b and miR-717 expression, which inhibit the expression of the transcriptional factor, osmotic response element binding protein (orebp) [11]. In comparison, studies of miRs in osmotic stress responses in fish are limited. Using zebrafish embryos, the expression of the miR-8 family (miR-200) in ionocytes was found to inhibit the expression of $\mathrm{Na}^{+} / \mathrm{K}^{+}$-exchanger regulatory cofactor (nherf1) to impair cellular responses to osmotic stress [12]. Using tilapia, decreased expression levels of miR-429 in gills under hyperosmotic stress was observed. An in-vivo inhibitory effect of miR-429 on the expression of osmoregulatory transcription factor (ostf1) in gills [13] and an inhibitory action of miR-30c on the expression of renal hsp70 under hyperosmotic stress [14] were reported. Moreover, differential expression patterns of miRs in gills of marbled eels, Anguilla marmorata adapted at different salinities [i.e. freshwater (FW), brackish-water or seawater $(\mathrm{SW})$ ] were described [15]. Japanese eels are euryhaline fish. The osmoregulatory tissue - gills provides an excellent model to study role of miRs in the regulation on plasticity of adaptive osmotic responses in vertebrates. The present study aimed to identify and characterize the involvement of miRs and messenger RNAs (mRNA) under osmotic perturbations. In this report, we used both exvivo gill filament and primary gill cell culture models, accompanied with miR-, transcriptome-sequencing and miR inhibition, to identify tonicity-sensitive miRs and to characterize their expressions in gill filaments.

\section{Results \\ Hyperosmotic treatment induced differential expression of transcriptional Factor-1/regulators, ion channels/ transporters and miR biogenesis factors in ex-vivo gill filament culture}

Gill filaments of eels were ex-vivo cultured in isotonic $\left(300 \mathrm{mOsmol}^{-1}\right)$ or hypertonic $\left(600 \mathrm{mOsmol}^{-1}\right) \mathrm{L}-15$ medium (penicillin-streptomycin (PS), gentamycin, FBS) at $23^{\circ} \mathrm{C}$ for 4,8 and $24 \mathrm{~h}$. Transcripts levels of ostf1, $\mathrm{Na}^{+} / \mathrm{Cl}^{-}$-taurine transporter (taut), $\mathrm{Na}^{+} / \mathrm{H}^{+}$exchange regulatory cofactor (nherf1), cystic fibrosis transmembrane regulator $(c f t r)$, and inward rectifying $\mathrm{K}^{+}$channel (kir), were significantly upregulated at hypertonic medium, in a time-dependent manner (Fig. 1). Moreover, the adenosine triphosphatases (ATPases), including the subunits of $\mathrm{Na}^{+} / \mathrm{K}^{+}$-ATPase [ATPase $\mathrm{Na}^{+} / \mathrm{K}^{+}$transporting subunit $\alpha 1$ (at1 $\alpha 1)$, ATPase $\mathrm{Na}^{+} / \mathrm{K}^{+}$transporting 

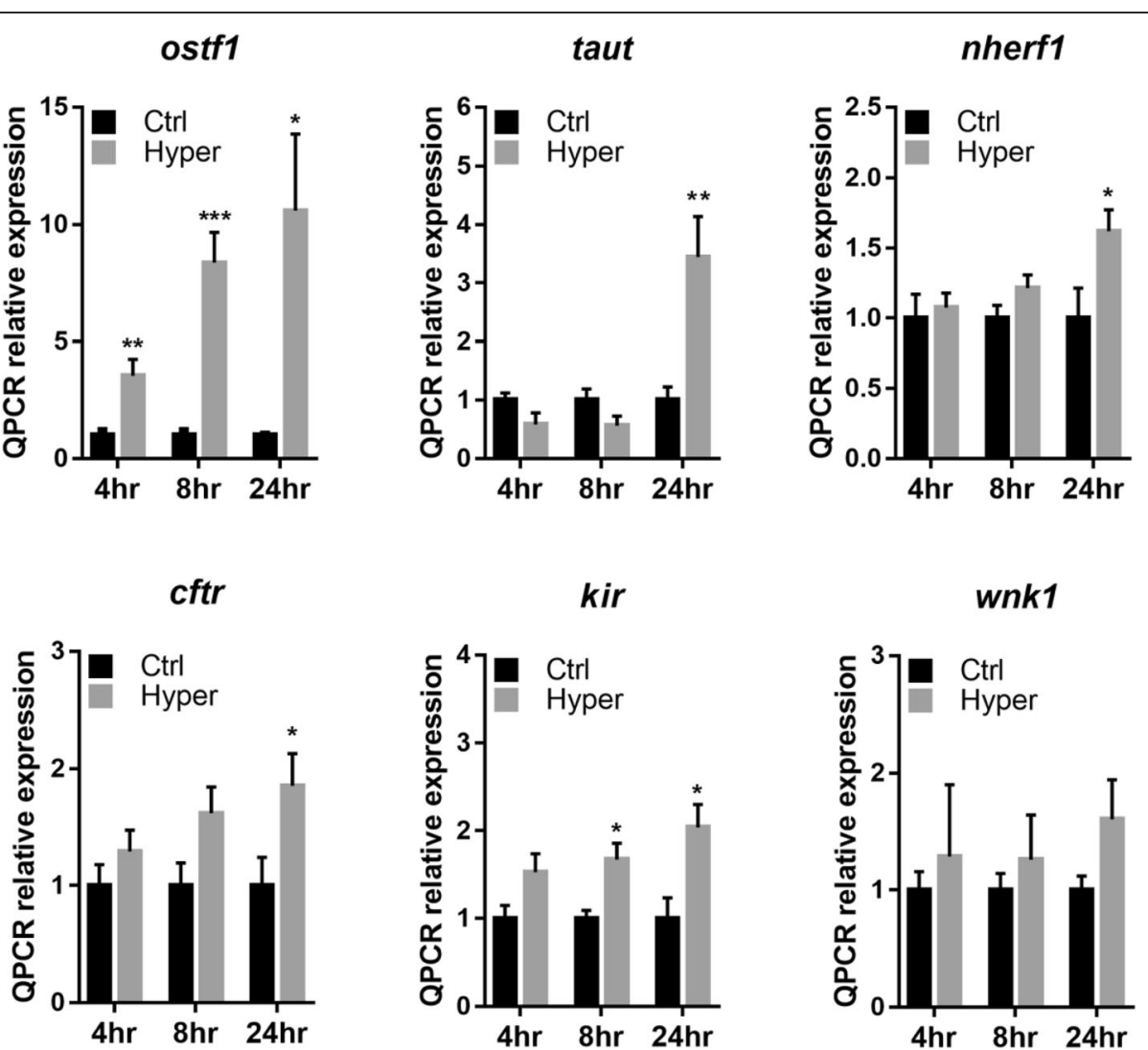

Fig. 1 Hypertonic stress induces differential gene expression of osmotic stress transcriptional factor and seawater ion transporter. Eel gill filaments were challenged in hyperosmotic (Hyper: $600 \mathrm{mOsmol} \mathrm{I}^{-1}$ ) media for 4, 8 and $24 \mathrm{~h}$. Control (Ctrl: $300 \mathrm{mOsmol} \mathrm{I}^{-1}$ ) or hypertonic-treated gill filaments were subsequently processed for analysis of tonicity-responsive gene expression by quantitative SYBR Green Real-Time PCR (qRT-PCR). Differential gene expression of osmotic-stress transcriptional factor (ostf1), $\mathrm{Na}^{+} / \mathrm{K}^{+}$exchange regulatory cofactor (nherf1), with-no-lysine kinase 1 (wnk1), inward rectifying $\mathrm{K}^{+}$channel (kir), cystic fibrosis transmembrane conductance regulator (cftr) and $\mathrm{Na}^{+} / \mathrm{Cl}^{-}$-taurine transporter (taut) was determined. Gapdh expression was used as internal control for normalization of target gene expression. Results (mean \pm s.e.m.) were from five independent experiments. ${ }^{*} P<0.05,{ }^{* *} P<0.01,{ }^{* * *} P<0.001$ vs control

subunit $\alpha 3$ (at1 $\alpha 3)$ ], and calcium-transporting ATPase 2 $(a t 2 b 2)$ were increased $(p<0.05)$. The mRNA expression level of V-type proton ATPase 1 ( $v p p 1$ ) was significantly reduced $(p<0.05)$ while the levels of aquaporin-3 (aqp3) and $\mathrm{Na}^{+} / \mathrm{K}^{+} / 2 \mathrm{Cl}^{-}$cotransporter (nkcc, s12a2) mRNA showed no noticeable changes (Fig. 2).

For the key factors involved in miR biogenesis, the mRNA expression levels of drosha RNase III endonuclease (drosha), exportin-5 (xpo5), dicer ribonuclease III (dicer-1) and argonaute-2 (ago2) in ex-vivo gill filaments were measured at 4,8 and $24 \mathrm{~h}$ of post-hypertonic treatment (Fig. 3). In general, the expression levels of drosha, and xpo5 transcripts were significantly reduced under hyperosmotic stress. The expression levels of dicer-1, however was significantly increased.

\section{Hyperosmotic treatment induced differential expression} of miRs in ex-vivo gill filament model

Gill filaments of eels were ex-vivo cultured in isotonic $\left(300 \mathrm{mOsmol} \mathrm{l}^{-1}\right)$ or hypertonic $\left(600 \mathrm{mOsmol} \mathrm{l}^{-1}\right) \mathrm{L}-15$ medium (PS, gentamycin, FBS) at $23^{\circ} \mathrm{C}$ for 4 and $8 \mathrm{~h}$. Total RNA was extracted and isolated using mirVana (Invitrogen). The $\mathrm{A}_{260} / \mathrm{A}_{280}$ value of the isolated RNA was $>1.8$, and the RIN was over 8 . Library construction was prepared for miR sequencing. A total of 568 million quality-trimmed raw reads were obtained from the small RNA sequencing (Additional file 1: ST1). De novo analysis identified 658 and $662 \mathrm{miR}$ precursors from the sequencing samples at 4 and $8 \mathrm{~h}$ respectively (Table 1 ). In consideration of Randford $p$-value, there were 82 and 84 miR precursors found to be not significant at 4 and $8 \mathrm{~h}$ treatment respectively. The corrected miR precursors were 576 and 578 at 4 and $8 \mathrm{~h}$ treatments. Figures $4 \mathrm{a}, \mathrm{b}$ show the volcanic plots of deregulated miRs of the samples. In the $4 \mathrm{~h}$ treatment, the expression levels of 81 miR precursors were found to be significantly different (DESeq2 adjusted $p$-value $<0.05$ ). There were $42 \mathrm{miRs}$ upregulated and 39 miRs downregulated. In $8 \mathrm{~h}$ treatment, there were 55 differentially expressed miR precursors in which $24 \mathrm{miR}$ precursors were upregulated and 

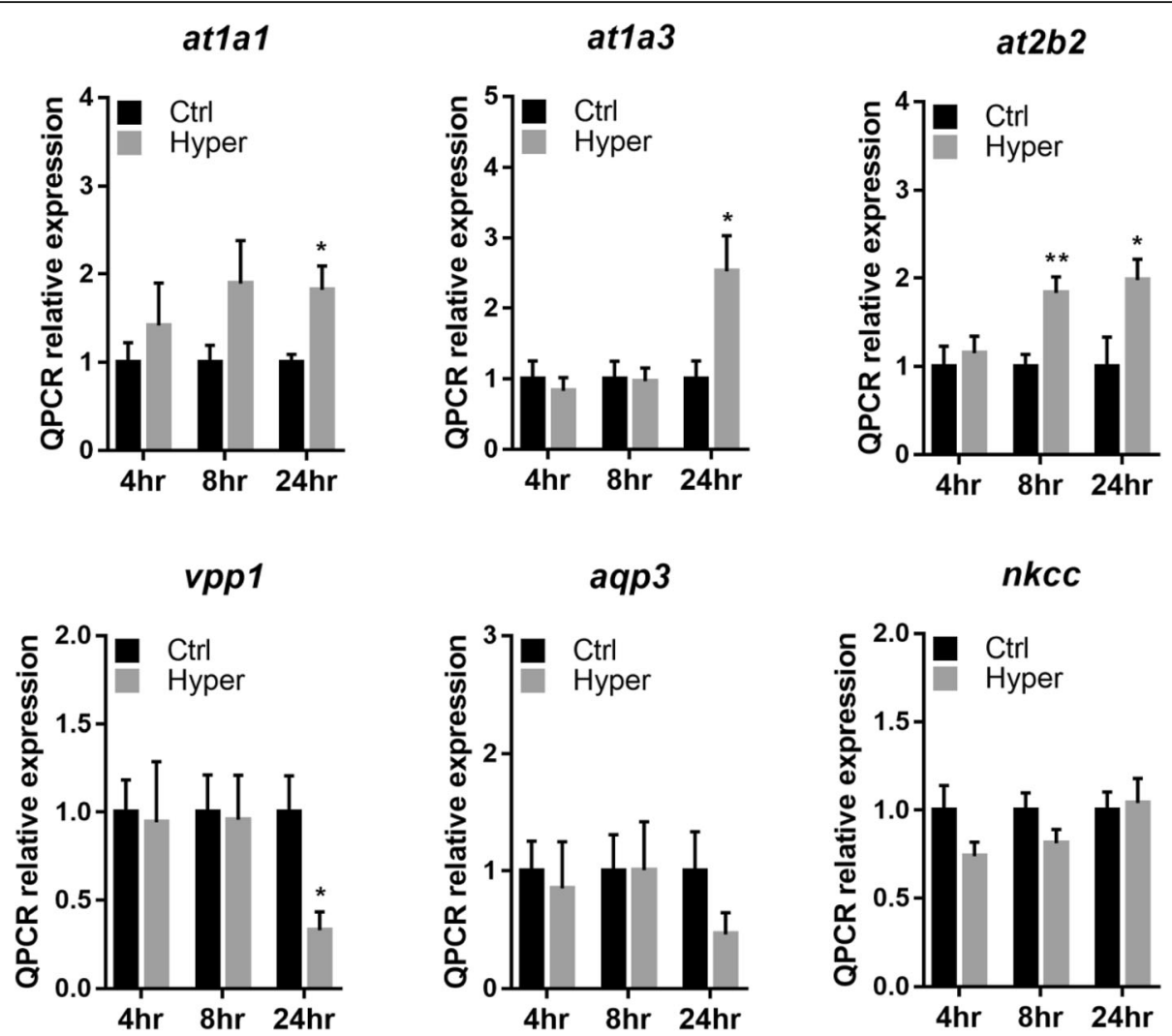

Fig. 2 Hypertonic stress induces differential gene expression of ion transporting enzyme in gill filament culture. Differential gene expression of ATPase $\mathrm{Na}^{+} / \mathrm{K}^{+}$-transporting subunit alpha 1 (at1a1), ATPase $\mathrm{Na}^{+} / \mathrm{K}^{+}$-transporting Subunit Alpha 3 (at 1a3), calcium-transporting ATPase 2 (at2b2), aquaporin 3 (aqp3), V-type proton ATPase 1 (vpp 1) and $\mathrm{Na}^{+} \mathrm{K}^{+} / 2 \mathrm{Cl}^{-}$-cotransporter ( $\mathrm{nkcc}$ ) was determined in control (Ctrl: $300 \mathrm{mOsmol} \mathrm{I-1)}$ or hypertonic-treated gill filaments ((Hyper: $600 \mathrm{mOsmol} \mathrm{I}^{-1}, 4,8,24 \mathrm{~h}$ ) by qRT-PCR. Relative expression level was normalized by gapdh. Results (mean \pm s.e.m.) were from five independent experiments. ${ }^{*} P<0.05$, ${ }^{* *} P<0.01 \mathrm{vs}$ control

31 were downregulated (DESeq2 adjusted $p<0.05$ ). To prioritize potential differentially regulated miRs, the significance of $p$-value was set to $p<0.001$. This led to a reduction in the numbers of differentially expressed miRs from 81 to 18 at $4 \mathrm{~h}$, and 79 to 10 at $8 \mathrm{~h}$ treatments. The Venn diagram (Fig. 4c) shows the common differentially expressed miRs at 4 and $8 \mathrm{~h}$. The two miRs, miR-29b-3p and miR-200b-3p were commonly downregulated at both time points of the hyperosmotic treatments (Fig. 4d). The differentially expressed miRs were validated using realtime PCR of the samples from isotonic and hypertonic treated gill filaments (Fig. 4e).

Since the suppression of gene expression is one of the major functions of miR, a transcriptome analysis of differential gene expression in ex-vivo gill filament-culture was conducted. There were 2085 differentially expressed genes (DEGs) at $4 \mathrm{~h}$ of the hypertonic treatment (Fig. 5a), including 890 upregulated genes and 1195 downregulated genes (Additional file 1: ST3). In $8 \mathrm{~h}$ of hyperosmotic treatment, 1670 DEGs including 841 upregulated genes and 829 downregulated genes were identified (Fig. 5b, Additional file 1: ST4). In the comparison of DEGs from the $4 \mathrm{~h}$ and $8 \mathrm{~h}$ treatments, 577 commonly upregulated and 711 downregulated genes were observed (Fig. 5c).

\section{Integrated miR-inhibition and Transcriptome analysis in} primary gill culture model

To underpin the gene targets, specific miR-inhibitors were used to block the activities of miR-29b-3p and miR-200b-3p. Figure 6a showed the effects of the inhibition on the individual miRs in primary gill cell culture. The inhibition of miR-29b-3p did not affect the expression level of miR-200b-3p, and vice versa. Supplementary Tables 5 and 6 showed the list of upregulated gene targets in cells after the treatment with miR-29b-3p and miR-200b-3p inhibitors, respectively. We overlaid the transcriptomic data of 4- and $8 \mathrm{~h}$-upregulated genes (ST3 \& ST4) and of miR-inhibition, to select two targetgenes [i.e., krueppel-like factor 4 (klf4) and homeobox protein meis2] for miR-29b-3p (Fig. 6b), and one targetgene (slc17a5) for miR-200b-3p (Fig. 6c). miRanda algorithm was then used to predict the binding of the individual miRs to the target genes. TransDecoder (version 5.0.2) was used to determine the coding regions 


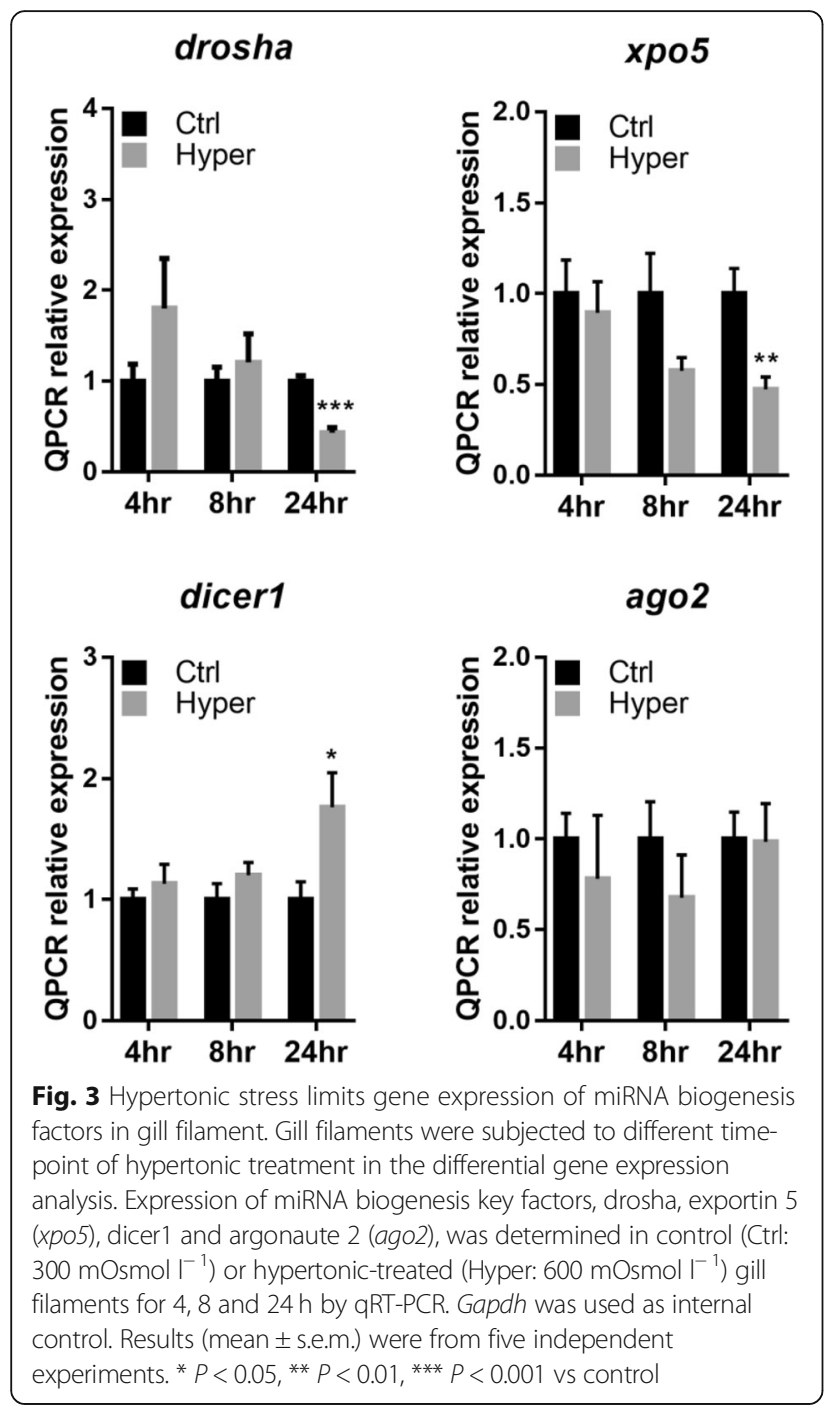

including 5' UTRs and 3' UTRs of transcripts [16]. The analysis showed that miR-29b-3p and miR-200b-3p could bind to the 3 ' untranslated region (3'UTR) of klf4 and slc17a5 (Fig. 6d). The binding site of klf4 is at 3'UTR between 447 to 468 , while the binding site of s17a5 is at the 3'UTR between 53 to 73 .

\section{Discussion}

miRs are a class of endogenous and conserved small RNA molecules $(\sim 22 \mathrm{nt})$ that play gene regulatory roles in targeting mRNAs for cleavage or translational repression [17]. Based on the finding of the recent studies, miRs are found to have a pivotal role in the regulation of fluid and electrolyte balance [18, 19]. It warrants further investigation to identify tonicity-inducible miRs and to determine their potential roles in osmoregulatory responses. In the present study, using ex-vivo gill filament culture model, we characterized the hyperosmotic responses with respective to the expression levels of some well-defined hyper- and hypo-osmotic genes (i.e. regulators and transporters). The involvement of miRbiogenesis genes and tonicity-responsive miRs were characterized. Possible mRNA candidates were predicted using genome-wide analysis of microRNA-mRNA interactome.

In the first part of the study, we characterized the exvivo gill filament culture model with regard to its responses to hyper-osmotic stress. The purpose is to establish a culture model, which retains the three-dimensional organization (primary and secondary lamellae) and takes into account of all the cell types [pavement cells (PVCs), chloride cells (CCs), mucous cells and undifferentiated cells] of gill tissues in experiments. In this study, numerous well-characterized hyper-osmotic and hypo-osmotic inducible genes were chosen to evaluate the functional responses and the validity of the culture. The hyperosmotic inducible genes, like ostf1 [20, 21], nherf [22], wnk1 [23] are regulatory proteins known to modulate gene transcription, apical trafficking of transmembrane G-protein coupled receptors/ion-transporters and epithelial chloride $\left(\mathrm{Cl}^{-}\right)$transport respectively. The hyperosmotic ostf1 induction was demonstrated in intact fish and primary gill epithelial cell culture [24]. Its expression could also be stimulated by the seawater-adapting hormone, cortisol [25]. The orchestrating role of ostf1 to integrate environmental and hormonal signals for osmosensory function was documented. In our study, ostf1 mRNA was stimulated in our ex-vivo culture model, under hyperosmotic stress. Our data also showed the upregulation of nherf1, suggesting its function in hyperosmotic adaptation. Intriguingly, it was reported that nherf1 negatively regulated the apical localization of $\mathrm{Na}^{+} / \mathrm{H}^{+}$exchanger (nhe) in renal brush border cells [26]. Nhe facilitates $\mathrm{Na}^{+}$retention in hypotonic solution, in exchange of $\mathrm{H}^{+}$, the process is important for freshwater adaptation. Nhef1 was found to be expressed in ionocytes in zebrafish embryos [12]. The downregulation of nherf1 blocked $\mathrm{Na}^{+}$accumulation in ionocytes. Presumably, in our study the upregulation of nherf1 in hyperosmotic gill filaments might downregulate nhe. Hyperosmotic acclimation is known to stimulate $\mathrm{Na}^{+}$ and $\mathrm{Cl}^{-}$secretion in ionocytes via the upregulation of kir, $\mathrm{Na}^{+} / \mathrm{K}^{+}$-ATPase (at1a1 and at1a3), and cftr. The sodium pump generated an extracellular $\mathrm{Na}^{+}$gradient to facilitate the transcellular co-transport of $\mathrm{Cl}^{-}$to cell cytoplasm, followed by $\mathrm{Cl}^{-}$secretion via apical $c f t r$. All these transporters were upregulated in the hyperosmotic treated gill filaments. The calcium-transporting ATPase $2(a t 2 b 2)$ is known to reduce intracellular $\mathrm{Ca}^{2+}$ to maintain calcium homeostasis, which could be perturbed by osmotic stress and seawater adaptation in eels $[27,28]$. The $\mathrm{Na}^{+} / \mathrm{K}^{+} /$ $2 \mathrm{Cl}^{-}$-cotransporter (s12a2) aids in the secondary transport of $\mathrm{Na}^{+}, \mathrm{K}^{+}$and $\mathrm{Cl}^{-}$, driven by $\mathrm{Na}^{+}$-gradient established by $\mathrm{Na}^{+} / \mathrm{K}^{+}$-ATPase [29]. However, there was no noticeable induction of $s l 2 a 2$ in this culture model. In addition to ion 
Table 1 Number of dysregulated miRNA caused by hypertonic stress

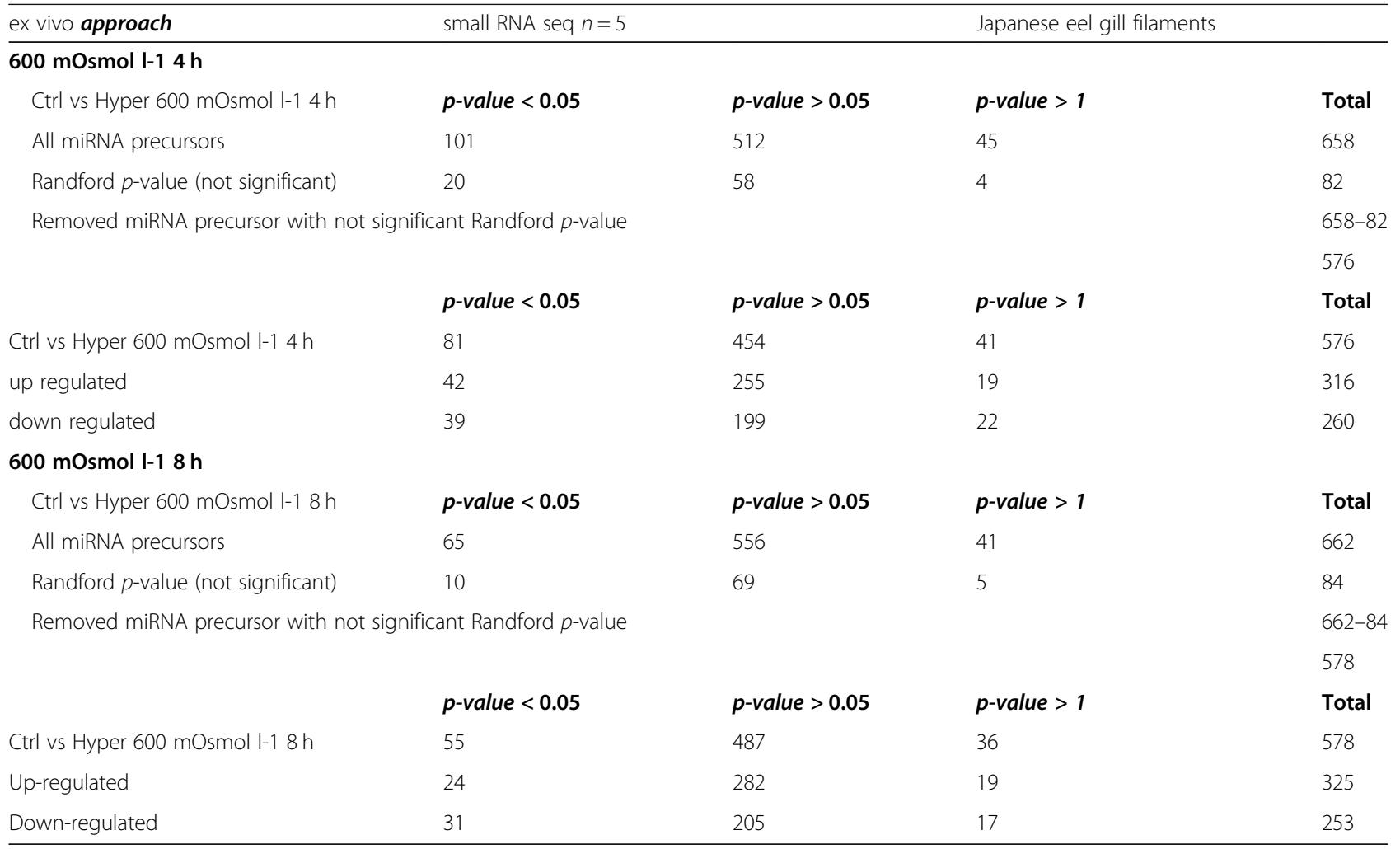

secretion, hyperosmotic acclimation involves the accumulation of organic osmolytes, like taurine to increase cellular osmolality. The expression levels of the taurine transporter, taut was upregulated in the hyperosmotic treated gill filaments. The aquaporin-3 (aqp-3) that mediates the translocation of water, glycerol, urea and other small solutes, was highly expressed in freshwater eel gills [30]. No significant reduction in its expression levels was measured in this study. On the other hand, the transporter (vpp1) involved in hypo-osmotic acclimation, was downregulated in the hyperosmotic treated gill filaments. As compared with the primary gill cell model, it is a twodimensional culture and comprises mostly PVCs [31, 32]. In the past studies, using primary gill PVC culture under hyperosmotic treatment, upregulation of ostf1, $\mathrm{Na}^{+} / \mathrm{K}^{+}$ATPase and taut mRNA expression were detected [31, 33]. The stimulation of cftr, kir, and nherf1 expression in the hyperosmotic-treated culture, has not yet been reported. Indeed, the expression of cftr and kir are known to be cell-specific, localized in seawater CCs. The low percentage of CCs in the primary cell culture made the model not representative as compared with the ex-vivo gill filament culture for studying gill physiology. Collectively, our data demonstrated that the ex-vivo gill filament culture exhibited distinctive responses to hyperosmotic acclimation. It would be a useful model to investigate underlying mechanisms of osmotic responses in fish gills.
With hindsight, the involvement of miRs in fluid and electrolyte transport has become apparent. A number of studies have illustrated the implications of miRs in ion transport in renal and non-renal tissues, showing a pivotal role of miRs in the regulation of fluid and electrolyte balance. In the present study, we studied the expression of four major factors involved in miR biogenesis, using the ex-vivo gill filament culture. Briefly, RNA polymerases II and III are involved in primary-miR (primiR) transcription [34, 35]. Upon nuclear cleavage of pri-miR by the Drosha RNase III endonuclease, a $\sim 60$ 70 nt miRNA precursor (pre-miRNA, a stem loop intermediate) is produced and transported from cell nucleus to cytoplasm in a Ran-GTPase dependent manner by the export receptor Exportin-5 [36, 37]. The pre-miRNA is then processed in the cytoplasm by the action of another RNase III endonuclease, Dicer to produce mature miR, followed by Argonaut proteins to target through sequence complementarity in RNA-induced silencing complex [38]. In this study, the mRNA expression levels of drosha, xpo5 and dicer1 were dysregulated under hyperosmotic treatment, indicating that the treatment modulated miR-biogenesis in gill cells. Since miRs take part in various aspects of physiological functions, including tissue remodeling and cell survival, it is anticipated an alternation of $\mathrm{miR}$ expression in the hyperosmotic treated gill filaments. Thus, miR sequencing was 
A

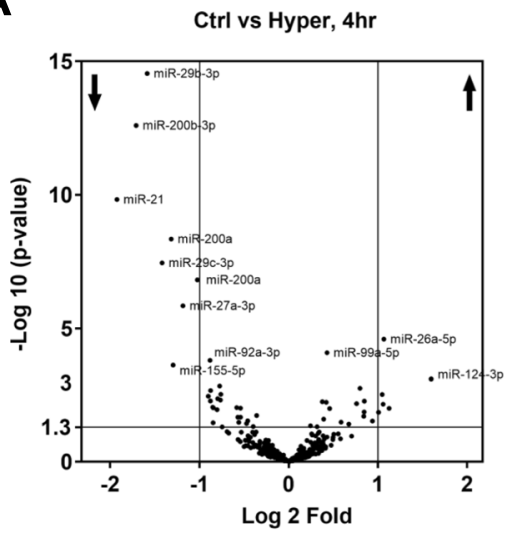

B

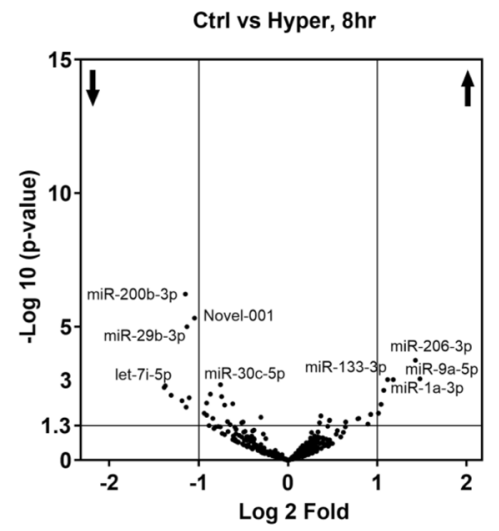

C

D
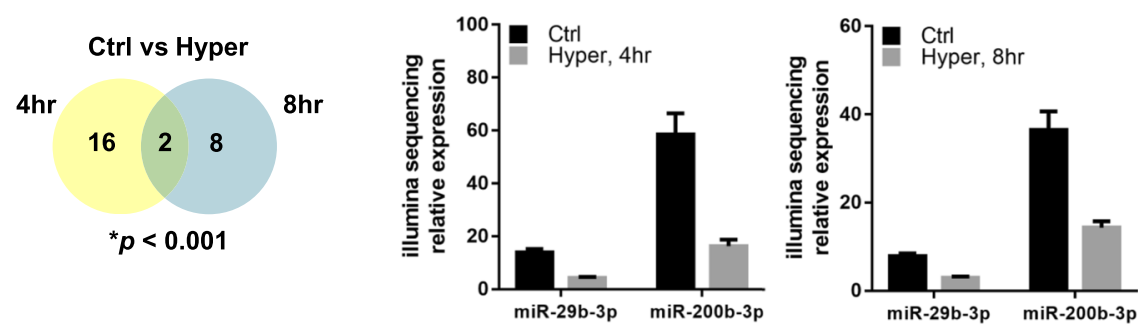

E
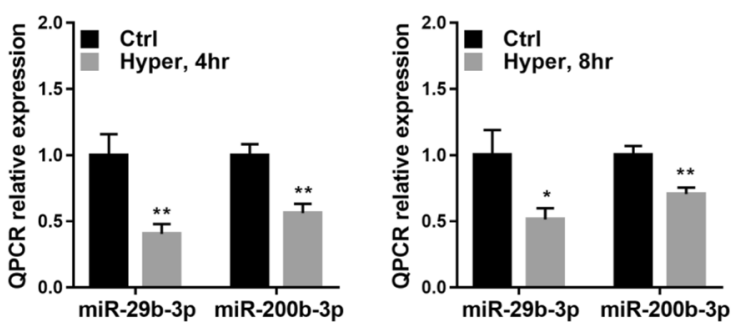

Fig. 4 Expression of miR-29 and miR-200 is dysregulated in gill filament culture under hypertonic stress. Gill filaments were challenged in hyperosmotic (Hyper: $600 \mathrm{mOsmol} \mathrm{I}^{-1}$ ) media for $4 \mathrm{~h}$ and $8 \mathrm{~h}$ and were subsequently processed for small RNA sequencing. a \& $\mathbf{b}$ Volcano plot showed differentially expressed miRs under $4 \mathrm{~h}(\mathbf{a})$ or $8 \mathrm{~h}(\mathbf{b})$ hypertonic treatment in gill filaments compared with the control. The $p<0.05$ and $\mid$ Log2 (fold change) $\mid>1$ were set as threshold for significantly differential expression. In $4 \mathrm{~h}$ hypertonic treatment, 81 differentially expressed miRs including 42 up-regulated miRs and 39 down-regulated miRs were identified, while in $8 \mathrm{~h}$ hypertonic treatment, 55 differentially expressed miRs including 24 up-regulated miRs and 31 down-regulated miRs were identified. $\mathbf{c}$ Venn diagram shows the similarity of differentially expressed miRs under $4 \mathrm{~h}$ and $8 \mathrm{~h}$ hypertonic treatments. Two miRs, miR-29b-3p and miR-200b-3p, with significant expression changes $(p<0.001)$ in both hypertonic treatment groups were selected for further analysis. $\mathbf{d}$ Bar charts exhibit the differential expression levels of miR-29b-3p and miR-200b$3 p$ in control and hypertonic groups ( 4 or $8 \mathrm{~h}$ ) based on deep sequencing data. e qRT-PCR was performed to validate the expression pattern of miR-29b-3p and miR-200b-3p. snRNA U6 was used as internal control for normalization of miRNA expression. Results (mean \pm s.e.m.) were from five independent experiments. ${ }^{*} P<0.05,{ }^{* *} P<0.01$ vs control

conducted using the gill filaments at two consecutive time-points. Bioinformatics analysis of the dysregulated miRs from the two time-points at high stringency of filtering $(p<0.001)$ shortlisted two miR candidates, miR29b-3p and miR-200b-3p. In the literatures, the family of miR-29 was found to respond to environmental stress and cellular repairing processes. In zebrafish model, the involvement of miR-29 in acute environmental stress (cold stress) was studied [39], in which the miR targeted on a core clock gene per2 to enhance cold tolerance of the fish larvae. Moreover, miR-29b was reported to play a role in cell regeneration, associated with the processes of cell survival and cytoskeleton reorganization in zebrafish [40]. Furthermore, miR-29 was recognized to 
A

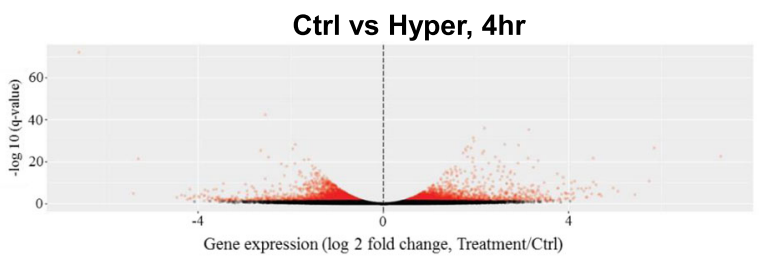

B

Ctrl vs Hyper, $8 \mathrm{hr}$

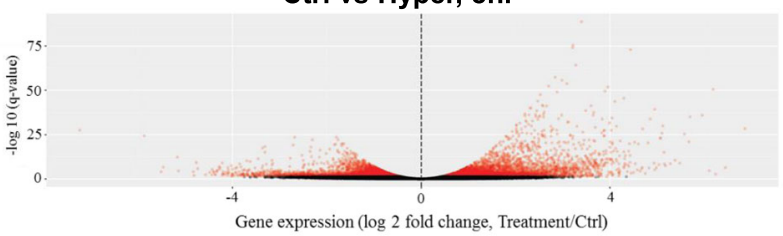

C

Up-regulated genes

4hr-
Hyper

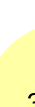

hr-

313

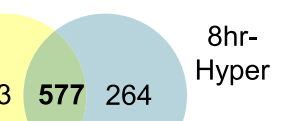

4hr-

Hyper
Down-regulated genes

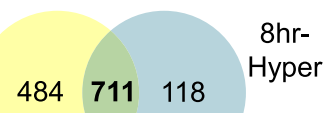

Fig. 5 Hypertonic stress mediates differential gene expression in gill filament culture. Total RNA of gill filaments with small RNA sequencing were subjected for transcriptome analysis $(n=5)$. a \& b Volcano plot showed DEGs under $4 \mathrm{~h}(\mathbf{a})$ or $8 \mathrm{~h}$ (b) hypertonic treatment (Hyper: $600 \mathrm{mOsmol}$ $\mathrm{I}^{-1}$ ) as compared to the control (Ctrl: $300 \mathrm{mOsmol} \mathrm{I}^{-1}$ ). DEGs with $\mid \log 2$ (fold change) $>1,-\log 10$-value $>2$ were set as threshold for significantly differential expression. In $4 \mathrm{~h}$ hypertonic treatment, 2085 DEGs including 890 upregulated genes and 1195 downregulated genes were identified, while in $8 \mathrm{~h}$ hypertonic treatment, 1670 DEGs including 841 upregulated genes and 829 downregulated genes were identified. c Venn diagram shows 577 commonly upregulated or 711 downregulated genes between $4 \mathrm{~h}$ and $8 \mathrm{~h}$ hypertonic treatment groups

modulate iron transport and oxidative stress in neurons of killifish brain [41]. Likewise, miR-200 family comprises of the $-\mathrm{a},-\mathrm{b}$ and $-\mathrm{c}$ members, those were reported to regulate somatic growth and neurogenesis in zebrafish $[42,43]$. A study showed the involvement of miR-200 in growth hormone $(\mathrm{GH})$ /insulin-like growth factor (IGF)signaling pathway and a high expression level of miR200 was associated with p53 to induce apoptosis [43]. The similar functional association was found to play roles in sperm motility of zebrafish [44]. Intriguingly, miR-200 was involved in epithelial ion transport to inhibit the expression of nherf1 in ionocytes of zebrafish embryos [12]. Our data agreed with the study to show that the downregulation of miR-200b-3p was accompanied with an upregulation of nherf1 in hyperosmotic gill filaments. Nonetheless, immunological function of miR200 on the regulation of Toll-like receptor pathways in sea cucumber was described [45].

In the last part of this study, we integrated the transcriptome data of time-course hyperosmotic treatment and of RNA inhibition, followed by miRanda algorithm analysis to determine the miR-mRNA binding. Klf4 and slc17a5 were identified to be the target-genes of miR29b-3p and miR-200b-3p, respectively. Klf4 is a zinc- finger transcriptional factor essential for terminal differentiation of intestinal epithelium and skin epidermis [46, 47]. A recent study demonstrated the role of Klf4 in the maintenance of ionocyte progenitor's population in zebrafish embryos [48]. Chloride cells in fish gills are ionocytes responsible for ion transport. During the course of seawater acclimation, there are significant increase of chloride cells in fish gills for hypo-osmotic adaptation [49]. Presumably, in this study, the hyperosmotic treatment of gill filament culture induced the expression of $k l f 4$ to increase chloride cell densities. The miR-200b-3p target-gene, slc17a5 belongs to the solute carrier family of transporters to transport amino acids [50], which can serve as organic osmolytes to regulate cellular osmolality, against hyperosmotic stress [51]. The implication of the data are consistent with the physiological responses of fish gills.

\section{Conclusions}

This is the first study to characterize the hypo-osmotic responses, and the dysregulation of miR-biogenesis factors/miRs in ex-vivo gill filament culture under hyperosmotic challenge. The data showed the culture retained the in-vivo molecular responses to upregulate hyper- 
A

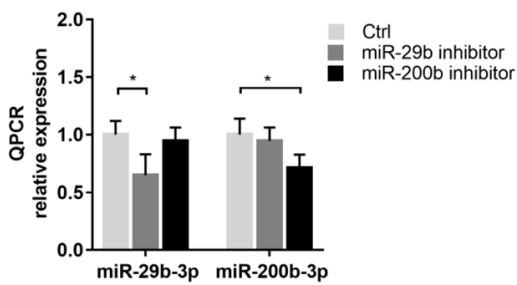

B

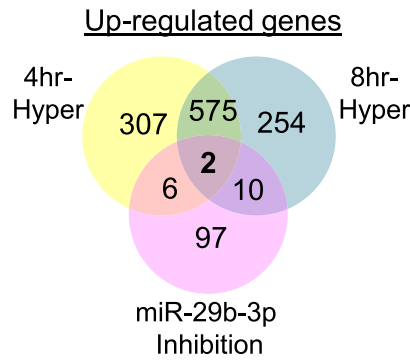

C

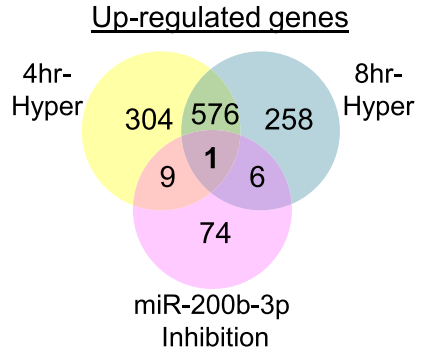

\begin{tabular}{lllll}
\hline & Gene Name & Gene Description & Log2 FC & $\boldsymbol{p}$-value \\
Potential Target of miR-29b-3p & KLF4 & Krueppel-like factor 4 & 3.68509 & 0.00262 \\
& MEIS2 & Homeobox protein Meis2 & 2.84079 & 0.00607 \\
Potential Target of miR-200b-3p & S17A5 & Sodium/sialic acid cotransporter & 2.299436 & 0.01565 \\
\hline
\end{tabular}

miR-29b-3p

klf4
miR-200b-3p

$$
\text { 3' gtagtaatgg TCCGTCATAAt 5' }
$$$$
\text { s17a5 }
$$

Fig. 6 Inhibition miR-29b-3p/miR-200b-3p in primary gill cell culture. To determine the biological effects of miR-29b-3p and miR-200b-3p through loss-of-function, two specific miRNA inhibitors (miR-29b-3p or miR-200b-3p) were transfected in gill cell culture. a qRT-PCR was performed to determine the efficiency of inhibition on miR-29b-3p and miR-200b-3p. Venn diagram shows the overlay of up-regulated genes in 4/8-h hypertonic (Hyper) treatment and $\mathbf{b}$ miR-29b-3p inhibition, and $\mathbf{c}$ miR200b-3p. The figures in parentheses represent the numbers of co-expressed genes. The potential target genes of miR-29b-3p and miR-200-3p were listed in the table. $\mathbf{d}$ Using miRanda algorithm, the full length of the miR was aligned against the target gene sequences. Thermodynamic stability of the RNA duplexes is based on these alignments and strict alignment in the seed region at position $2-7 \mathrm{bp}$ of the miR to the mRNA sequence. ${ }^{*} P<0.05$ vs control

osmotic factors/transporters and to downregulate hypoosmotic transporter. Using multiple experimental approaches, two miRs and two target genes were identified to be involved in the hyperosmotic challenge of gill filaments. The two miRs were predicted to target a cluster of genes involved in osmoregulation. MiR inhibition analysis further identified two gene targets, those are essential for differentiation of gill chloride cells and the regulation of cellular osmolality. There are many other tonicity-responsive miRs and genes were identified in this study. The data support further analysis of other miRs and transcripts to elucidate their regulatory roles in osmotic responses.

\section{Methods}

Fish maintenance, in-vitro and ex-vivo gill culture model Japanese eels were obtained from fish vendor Lok $\mathrm{Fu}$ market. Japanese eels (600-800 g) was reared in fiberglass tanks supplied with charcoal-filtering aerated freshwater water at $18-20{ }^{\circ} \mathrm{C}$ under a $12 \mathrm{~L}: 12 \mathrm{D}$ photoperiod for at least 2 weeks to facilitate acclimation before experiments. The eel was handled in accordance to the guidelines and regulation of Hong Kong Baptist University. The fish were anesthetized with 0.1\% MS-222 (Sigma) and perfused with phosphate buffered saline (PBS, $\mathrm{pH}$ 7.7). Gill tissue was excised and washed for the procedures of ex-vivo gill filament culture. Briefly, gill arches were cut every $5 \mathrm{~mm}$ interval with intact primary filaments, washed with PBS, pH 7.7 and maintained in Leibovitz's L-15 medium (Gibco, Invitrogen, Grand Island, NY, USA) supplemented with $10 \%$ fetal bovine serum (FBS, HyClone ${ }^{\oplus}$, Perbio Sciences, Logan, UT, USA), 1\% penicillin/streptomycin, $0.5 \%$ fungizone (Gibco, Invitrogen). The culture was incubated at $23^{\circ} \mathrm{C}$.

For primary gill cell culture, the gill filaments were then subject to hyperosmotic-treatment. For primary gill 
cell culture, gill filaments were cut into small fragments and subjected to two cycles of tryptic digestion $(0.5 \%$ trypsin $+5.3 \mathrm{mmol}^{-1}$ EDTA) (Sigma), each for $20 \mathrm{~min}$ at room temperature in a rotator (300 r.p.m.). Cell suspension was filtered through stainless steel mesh (104 and $73.7 \mu \mathrm{m}$, Sigma), washed with PBS, pH 7.7 and finally resuspended in Leibovitz's L-15 medium (Gibco, Invitrogen, Grand Island, NY, USA) supplemented with $10 \%$ fetal bovine serum (FBS, HyClone ${ }^{\circ}$, Perbio Sciences, Logan, UT, USA), $1 \%$ penicillin/streptomycin, $0.5 \%$ fungizone (Gibco, Invitrogen) and seeded at a density of $2 \times 10^{6}$ cells $\mathrm{cm}^{-2}$ onto collagen coated culture plates (Iwaki, Chiba, Japan). The culture was incubated at $23^{\circ} \mathrm{C}$ in a growth chamber with humidified air. One day after seeding, each culture well was rinsed with PBS ( $\mathrm{pH} 7.7$ ) to remove mucous and unattached cells. The culture was subject to miR-knockdown analysis.

\section{Hyperosmotic challenge and RNA preparation}

Hypertonic medium was prepared by an addition of $3 \%$ of $5 \mathrm{M} \mathrm{NaCl}$ to the Leibovitz's L-15 medium (300 mOsmol $\mathrm{l}^{-1}$ ). The osmolality of freshly prepared hypertonic media was measured by a vapor pressure osmometer (Wescor, 5500XR, Logan, UT, USA). For the gill filament culture, tissue samples were exposed to the Leibovitz's L-15 medium (300 mOsmol $\mathrm{l}^{-1}$ ) or the medium with an adjusted osmolality of $600 \mathrm{mOsmol}^{-1}$ for 4,8 and $24 \mathrm{~h}$. After the hypertonic treatment, total RNA of gill filaments were extracted using mirVana miRNA isolation kit (Invitrogen) according to the manufacturer's instruction. RNA quality was assessed using the Agilent 2100 Bioanalyzer system and samples with a RNA Integrity Number (RIN) greater than 8 was used for small RNA and RNA library constructions.

\section{Small RNA sequencing}

Twenty small RNA libraries were constructed [five replicates per individual time points $(4$ and $8 \mathrm{~h}$ ) per individual osmotic conditions (300 and $600 \mathrm{mOsmol} \mathrm{l}^{-1}$ )] using $5 \mu \mathrm{g}$ of total RNA from each sample. Short RNA transcripts (18-30 nucleotides long) were resolved and isolated using Polyacrylamide gel electrophoresis (PAGE) gels. The selected small RNA molecules were ligated with $3^{\prime}$ and $5^{\prime}$ adapters, followed by the synthesis of single stranded complementary DNA (cDNA) using SuperScript II Reverse Transcriptase (Invitrogen). The cDNA was then amplified using indexing primers. After quantitative real-time PCR (qRT-PCR) amplification, the library size was determined using the Bioanalyzer (Agilent Technologies 2100). Concentrations of the libraries were tested using qRT-PCR (EvaGreen). The libraries were then processed by the Beijing Genomics Institute (BGI). Single-end read (50 bases pair (bp) read-length) was sequenced using the BGISEQ-500RS sequencer to produce at least $25 \mathrm{M}$ clean reads per sample. Sequencing statistic was shown in Additional file 1: ST1. The adaptor sequences were trimmed and Phred quality score less than 20 were removed. The sequencing reads were mapped to the Anguilla japonica reference genome from NCBI (AVPY00000000.1, https://www.ncbi.nlm.nih.gov/Traces/ wgs/?val=AVPY01) using mapper.pl module of the mirDeep2 package [52]. MicroRNAs were identified using the miRDeep2 procedure and final results were annotated for sequence similarity to known miRNAs in miRBase databases [53]. The quantification results produced by the quantifier.pl module of the mirDeep2 package were then used to compare the expression of miRNA in the different time points with the DESeq2 [54].

\section{Transcriptome sequencing and miRNA target genes prediction}

Total RNA extracted from the same set of gill filament samples were subjected for cDNA library construction. The libraries were processed by BGI. Single-end reads, $50 \mathrm{bp}$ read-length, were sequenced on the BGISEQ-500RS sequencer produce at least $25 \mathrm{M}$ clean reads per sample. Sequence-reads were in turn trimmed according to BWA's - q algorithm [55] and the sequence reads were quantified using the Anguilla japonica transcriptome assembly (Kallisto version 0.43.0) [56, 57]. Read-count data were then subjected to differential expression analysis using edgeR package [58]. Genes with $\mid \log 2$ (fold change: treatment/ control) $\mid>0.5$ and $q$-value $<0.01$ were considered as differentially expressed genes (DEGs). Furthermore, Ingenuity Pathway Analysis (IPA', QIAGEN Redwood City, www.qiagen.com/ingenuity) was used to decipher the effect of hypertonic treatment in gill filament. In the bioinformatics analysis, all the pathways, diseases or biofunctions with $P<0.05$ were considered as statistically significant.

The miRanda algorithm [59] was used to predict genes targeted the miRNAs as previously described [60]. Briefly, the whole length of the miRNA was first aligned against the mRNA sequences. Thermodynamic stability of the RNA duplexes based on these alignments was calculated. Strict alignment in the seed region at position $2-7 \mathrm{bp}$ of the miRNA to the mRNA sequence is required, of which the region is the key determinant in miRNA-mRNA recognition [61]. The target genes were then subjected to Database for Annotation, Visualization and Integrated Discovery (DAVID) v6.7 [62] to understand the functional roles of hypertonic treatmentderegulated miRNAs.

\section{Real-time PCR analysis of identified miRNAs and differential gene expression under hyperosmotic stress} Gill filaments were exposed to hyperosmotic treatment $\left(600 \mathrm{mOsmol} \mathrm{l}^{-1}\right)$. After $4 \mathrm{~h}$ or $8 \mathrm{~h}$ incubation, total RNA of gill filaments were extracted using mirVana 
miRNA isolation kit (Invitrogen). For mature miRNA detection and quantification, $250 \mathrm{ng}$ of total RNA was reverse transcribed in HiSpec buffer with miScript II RT kit (Qiagen). The cDNA generated is used for RT-PCR with miScript SYBR green PCR kit (Qiagen). Human small nuclear RNA 6 (RNU 6) (Qiagen: MS00033740) was used for normalizing RT-PCR of miRNA. Sequences for primers targeting miR-29b-3p and miR-200b-3p are miR-29b-3p: 5'- UAGCACCAUUUGAAAUCAGUGU-3'; miR-200b3p: 5'-UAAUACUGCCUGGUAAU GAUG-3'. For differential gene expression analysis, cDNA generated with SuperScript VILO master mix (Invitrogen) was used for qRT-PCR analysis on hyper-osmotic and hypo-osmotic inducible genes. Sequences for specific primers targeting Japanese eel genes are shown in Additional file 1: ST2. Relative quantification of miRNA and mRNA expression was calculated based on delta delta $\mathrm{Ct}(\Delta \Delta \mathrm{Ct})$ values [57].

\section{Inhibition of miR activity}

For experiments of miR-inhibition (miRi), primary gill cells were transfected with either mirVana ${ }^{\mathrm{Tm}}$ miRNA inhibitor negative control \#1 (Thermo Fisher, Cat \#4464076) or mirVana $^{\text {Tx }}$ target miRNA inhibitors (Thermo Fisher) at $100 \mathrm{nM}$ in L-15 culture medium using Lipofectamine 2000 according to the manufacturer's instructions (Invitrogen). After $24 \mathrm{~h}$ treatment, total RNA of miR-transfected cells was harvested for transcriptome sequencing. Quantitative RT-PCR was performed to assess the efficiency of inhibition. Sequences for miRNA inhibitors targeting miR-29b-3p, and miR-200-3p are 5'-UAGCACC AUUUGAAAUCAGUGU3' (Thermo Fisher, Assay ID: MH10432) and 5'-UAAUACUGC CUGGUAAUGAUG-3' (Thermo Fisher, Assay ID: MH11741), respectively.

\section{Statistical analysis}

Statistical analyses of DEGs and differentially expressed miRNA profiles were performed using GraphPad Prism 6 (GraphPad Software, San Diego, CA). Student's t-test was used to assess for potential differences between control (isotonic) and treatment (hypertonic) groups. We reported statistical significance at ${ }^{*} P<0.05,{ }^{* *} P<0.01$ and **** $P<0.001$. Values were expressed as mean \pm S.E.M.

\section{Supplementary information}

Supplementary information accompanies this paper at https://doi.org/10. 1186/s12864-020-6630-0.

Additional file 1: Table S1. Clean read stats: Small RNA sequencing statistic; Table S2. Primer sequence for RT-PCR: List of primer used for Real-time PCR analysis. Table S3. mRNA seq-4 h hyper: List of DEGs identified in eel gill filament culture under $4 \mathrm{~h}$ hypertonic stress treatment. Table S4. mRNAseq-8 h hyper: List of DEGs in eel gill filament culture under $8 \mathrm{~h}$ hypertonic stress treatment. Table S5. mRNAseq-miR-29b inhibition. List of upregulated genes in primary gill cell culture, after miR29b-3p inhibition. Table S6. mRNAseq-miR-200b inhibition: List of upregulated genes in primary gill cell culture, after miR-200b-3p inhibition.

\section{Abbreviations}

aqp-3: Aquaporin-3; at1a1: ATPase $\mathrm{Na}^{+} / \mathrm{K}^{+}$transporting subunit a1; at1a3: ATPase $\mathrm{Na}^{+} / \mathrm{K}^{+}$transporting subunit a3; at2b2: Calcium-transporting ATPase 2; ATP: Adenosine triphosphate; ATPases: Adenosine triphosphatases; BGl: Beijing Genomics Institute; bp: Bases pair; CCs: Chloride cells; cDNA: Complementary DNA; cftr: Cystic fibrosis transmembrane regulator; DEGs: Differentially expressed genes; dicer-1: Dicer ribonuclease III; drosha: Drosha RNase III endonuclease; FBS: Fetal bovine serum; FW: Freshwater; GH: Growth Hormone; IGF: Insulin-like growth factor; Kir: Inward rectifying $\mathrm{K}^{+}$channel; Klf4: Kruppel-like factor 4; L-15: Leibovitz's L15; miR: MicroRNA; Nhe: $\mathrm{Na}^{+} / \mathrm{H}^{+}$exchanger; nherf1: $\mathrm{Na}^{+} / \mathrm{K}^{+}$-exchanger regulatory cofactor; $\mathrm{Nkcc}$, s12a2: $\mathrm{Na}^{+} / \mathrm{K}^{+} / 2 \mathrm{Cl}^{-}$cotransporter; orebp: Osmotic response element binding protein; ostf1: Osmoregulatory transcription factor PAGE: Polyacrylamide gel electrophoresis; Pri-miR: Primary-miR; PS: Penicillinstreptomycin; PVC: Pavement cells; RIN: RNA Integrity Number; S17a5, Slc17a5: Solute carrier family 17 member 5; SW: Seawater; taut: $\mathrm{Na}^{+} / \mathrm{Cl}^{-}$ taurine transporter; UTR: Untranslated region; vpp1: V-type proton ATPase 1; wnk1: With-no-lysine kinase; xpo5: Exportin-5

\section{Acknowledgements}

Keng Po Lai is supported by Hong Kong SAR, Macao SAR and Taiwan Province Talent Young Scientist Program of Guangxi.

\section{Authors' contributions}

Conceived and designed the experiments: KPL, CKCW. Performed the experiments: $\mathrm{HMN}, \mathrm{JCHH}$. Analyzed the data: HMN, KPL, CKCW, WN, JHLH. Wrote the manuscript: HMN, KPL, CKCW. All authors have read and approved the final manuscript. HMN and JHLH contributed equally to this work.

\section{Funding}

This whole project including the sample preparation, sequencing and data analysis was supported by General Research Fund (HKBU12162016), Research Grant Council Hong Kong, to Dr. Chris KC Wong (Hong Kong Baptist University).

\section{Availability of data and materials}

The datasets supporting the conclusions of this article are included within the article and its additional files.

\section{Ethics approval and consent to participate}

All fish experiments were conducted following ethical principles and procedures approved by the guidelines and regulation at Hong Kong Baptist University.

\section{Consent for publication}

Not applicable.

\section{Competing interests}

The authors declare that they have no competing interests.

\section{Author details}

${ }^{1}$ Croucher Institute for Environmental Sciences, Department of Biology, Hong Kong Baptist University, Kowloon Tong, HKSAR, Hong Kong. ${ }^{2}$ School of Life Sciences, Simon F.S. Li Marine Science Laboratory, State Key Laboratory of Agrobiotechnology, The Chinese University of Hong Kong, Shatin, HKSAR, Hong Kong. ${ }^{3}$ Guanxi Key Laboratory of Tumor Immunology and Microenvironmental Regulation, Guilin Medical University, Huan Cheng North 2nd Road 109, Guilin 541004, People's Republic of China.

Received: 4 November 2019 Accepted: 26 February 2020

Published online: 04 March 2020

\section{References}

1. Evans DH. Teleost fish osmoregulation: what have we learned since August Krogh, Homer Smith, and Ancel Keys. Am J Physiol Regul Integr Comp Physiol. 2008:295(2):R704-13.

2. Evans DH, Piermarini PM, Choe KP. The multifunctional fish gill: dominant site of gas exchange, osmoregulation, acid-base regulation, and excretion of nitrogenous waste. Physiol Rev. 2005;85(1):97-177. 
3. Hwang PP, Lee TH, Lin LY. Ion regulation in fish gills: recent progress in the cellular and molecular mechanisms. Am J Physiol Regul Integr Comp Physiol. 2011;301(1):R28-47.

4. Takei $Y$, Hiroi J, Takahashi H, Sakamoto T. Diverse mechanisms for body fluid regulation in teleost fishes. Am J Physiol Regul Integr Comp Physiol. 2014; 307(7):R778-92.

5. Pietrzykowski AZ, Friesen RM, Martin GE, Puig SI, Nowak CL, Wynne PM, et al. Posttranscriptional regulation of BK channel splice variant stability by miR-9 underlies neuroadaptation to alcohol. Neuron. 2008;59(2):274-87.

6. Xiao L, Xiao J, Luo X, Lin H, Wang Z, Nattel S. Feedback remodeling of cardiac potassium current expression: a novel potential mechanism for control of repolarization reserve. Circulation. 2008;118(10):983-92.

7. Yang B, Lin H, Xiao J, Lu Y, Luo X, Li B, et al. The muscle-specific microRNA miR-1 regulates cardiac arrhythmogenic potential by targeting GJA1 and KCNJ2. Nat Med. 2007:13(4):486-91.

8. Ceolotto G, Papparella I, Bortoluzzi A, Strapazzon G, Ragazzo F, Bratti P, et al. Interplay between miR-155, AT1R A1 166C polymorphism, and AT1R expression in young untreated hypertensives. Am J Hypertens. 2011;24(2):241-6.

9. Sober S, Laan M, Annilo T. MicroRNAs miR-124 and miR-135a are potential regulators of the mineralocorticoid receptor gene (NR3C2) expression. Biochem Biophys Res Commun. 2010;391(1):727-32.

10. Elvira-Matelot E, Zhou XO, Farman N, Beaurain G, Henrion-Caude A, Hadchouel J, et al. Regulation of WNK1 expression by miR-192 and aldosterone. J Am Soc Nephrol. 2010;21(10):1724-31.

11. Huang W, Liu H, Wang T, Zhang T, Kuang J, Luo Y, et al. Tonicity-responsive microRNAs contribute to the maximal induction of osmoregulatory transcription factor OREBP in response to high-NaCl hypertonicity. Nucleic Acids Res. 2011;39(2):475-85.

12. Flynt AS, Thatcher EJ, Burkewitz K, Li N, Liu Y, Patton JG. miR-8 microRNAs regulate the response to osmotic stress in zebrafish embryos. J Cell Biol. 2009;185(1):115-27.

13. Yan B, Zhao LH, Guo JT, Zhao JL. miR-429 regulation of osmotic stress transcription factor 1 (OSTF1) in tilapia during osmotic stress. Biochem Biophys Res Commun. 2012;426(3):294-8.

14. Yan B, Guo JT, Zhao LH, Zhao JL. MiR-30c: a novel regulator of salt tolerance in tilapia. Biochem Biophys Res Commun. 2012;425(2):315-20.

15. Wang $X$, Yin D, Li P, Yin S, Wang L, Jia Y, et al. MicroRNA-sequence profiling reveals novel Osmoregulatory MicroRNA expression patterns in Catadromous eel Anguilla marmorata. PLoS One. 2015;10(8):e0136383.

16. Haas BJ, Papanicolaou A, Yassour M, Grabherr M, Blood PD, Bowden J, et al. De novo transcript sequence reconstruction from RNA-seq using the trinity platform for reference generation and analysis. Nat Protoc. 2013;8(8):1494-512.

17. Bartel DP. MicroRNAs: target recognition and regulatory functions. Cell. 2009;136(2):215-33.

18. Chandrasekaran K, Karolina DS, Sepramaniam S, Armugam A, Wintour EM, Bertram JF, et al. Role of microRNAs in kidney homeostasis and disease. Kidney Int. 2012;81(7):617-27.

19. Elvira-Matelot $E$, Jeunemaitre $X$, Hadchouel J. Regulation of ion transport by microRNAs. Curr Opin Nephrol Hypertens. 2011;20(5):541-6.

20. Chow SC, Wong CK. Regulatory function of hyperosmotic stress-induced signaling cascades in the expression of transcription factors and osmolyte transporters in freshwater Japanese eel primary gill cell culture. J Exp Biol. 2011;214(Pt 8):1264-70.

21. Fiol DF, Kultz D. Rapid hyperosmotic coinduction of two tilapia (Oreochromis mossambicus) transcription factors in gill cells. Proc Natl Acad Sci U S A. 2005;102(3):927-32.

22. Li J, Callaway DJ, Bu Z. Ezrin induces long-range interdomain allostery in the scaffolding protein NHERF1. J Mol Biol. 2009;392(1):166-80.

23. Shekarabi M, Zhang J, Khanna AR, Ellison DH, Delpire E, Kahle KT. WNK kinase signaling in ion homeostasis and human disease. Cell Metab. 2017; 25(2):285-99.

24. Fiol DF, Chan SY, Kultz D. Regulation of osmotic stress transcription factor 1 (Ostf1) in tilapia (Oreochromis mossambicus) gill epithelium during salinity stress. J Exp Biol. 2006;209(Pt 16):3257-65.

25. Chow SC, Tse WK, Wong CK. Dexamethasone (DEX) induces osmotic stress transcription factor 1 (Ostf1) through the Akt-GSK3beta pathway in freshwater Japanese eel gill cell cultures. Biol Open. 2013;2(5):487-91.

26. Weinman EJ, Steplock D, Donowitz M, Shenolikar S. NHERF associations with sodium-hydrogen exchanger isoform 3 (NHE3) and ezrin are essential for CAMP-mediated phosphorylation and inhibition of NHE3. Biochemistry. 2000;39(20):6123-9.
27. Gu J, Law AY, Yeung BH, Wong CK. Activation of gill Ca2+-sensing receptor as a protective pathway to reduce Ca2+-induced cytotoxicity. J Mol Endocrinol. 2014;53(2):155-64.

28. Gu J, Law AY, Yeung BH, Wong CK. Characterization of stanniocalcin 1 binding and signaling in gill cells of Japanese eels. J Mol Endocrinol. 2015; 54(3):305-14.

29. Tse WK, Au DW, Wong CK. Characterization of ion channel and transporter mRNA expressions in isolated gill chloride and pavement cells of seawater acclimating eels. Biochem Biophys Res Commun. 2006;346(4):1181-90.

30. Cutler CP, Cramb G. Branchial expression of an aquaporin 3 (AQP-3) homologue is downregulated in the European eel Anguilla anguilla following seawater acclimation. J Exp Biol. 2002;205(Pt 17):2643-51.

31. Tse WK, Au DW, Wong CK. Effect of osmotic shrinkage and hormones on the expression of $\mathrm{Na}+/ \mathrm{H}+$ exchanger-1, $\mathrm{Na}+/ \mathrm{K}+/ 2 \mathrm{Cl}$ - cotransporter and $\mathrm{Na}+/ \mathrm{K}+-$ ATPase in gill pavement cells of freshwater adapted Japanese eel, Anguilla japonica. J Exp Biol. 2007;210(Pt 12):2113-20.

32. Tse WK, Chow SC, Wong CK. The cloning of eel osmotic stress transcription factor and the regulation of its expression in primary gill cell culture. J Exp Biol. 2008;211(Pt 12):1964-8.

33. Chow SC, Ching LY, Wong AM, Wong CK. Cloning and regulation of expression of the $\mathrm{Na}+-\mathrm{Cl}-$-taurine transporter in gill cells of freshwater Japanese eels. J Exp Biol. 2009;212(Pt 20):3205-10.

34. Dieci G, Fiorino G, Castelnuovo M, Teichmann M, Pagano A. The expanding RNA polymerase III transcriptome. Trends Genet. 2007;23(12):614-22.

35. Lin SL, Kim H, Ying SY. Intron-mediated RNA interference and microRNA (miRNA). Front Biosci. 2008;13:2216-30.

36. Lee $Y$, Jeon K, Lee JT, Kim S, Kim VN. MicroRNA maturation: stepwise processing and subcellular localization. EMBO J. 2002;21(17):4663-70.

37. Lund E, Guttinger S, Calado A, Dahlberg JE, Kutay U. Nuclear export of microRNA precursors. Science. 2004;303(5654):95-8.

38. Lee Y, Ahn C, Han J, Choi H, Kim J, Yim J, et al. The nuclear RNase III Drosha initiates microRNA processing. Nature. 2003;425(6956):415-9.

39. Hung IC, Hsiao YC, Sun HS, Chen TM, Lee SJ. MicroRNAs regulate gene plasticity during cold shock in zebrafish larvae. BMC Genomics. 2016; 17(1):922.

40. Fuller-Carter PI, Carter KW, Anderson D, Harvey AR, Giles KM, Rodger J. Integrated analyses of zebrafish miRNA and mRNA expression profiles identify miR-29b and miR-223 as potential regulators of optic nerve regeneration. BMC Genomics. 2015;16:591.

41. Ripa R, Dolfi L, Terrigno M, Pandolfini L, Savino A, Arcucci V, et al. MicroRNA miR-29 controls a compensatory response to limit neuronal iron accumulation during adult life and aging. BMC Biol. 2017;15(1):9.

42. Choi PS, Zakhary L, Choi WY, Caron S, Alvarez-Saavedra E, Miska EA, et al. Members of the miRNA-200 family regulate olfactory neurogenesis. Neuron. 2008;57(1):41-55.

43. Jing J, Xiong S, Li Z, Wu J, Zhou L, Gui JF, et al. A feedback regulatory loop involving p53/miR-200 and growth hormone endocrine axis controls embryo size of zebrafish. Sci Rep. 2015;5:15906.

44. Xiong S, Ma W, Jing J, Zhang J, Dan C, Gui JF, et al. An miR-200 cluster on chromosome 23 regulates sperm motility in Zebrafish. Endocrinology. 2018; 159(5):1982-91.

45. Lv Z, Li C, Zhang P, Wang Z, Zhang W, Jin CH. MiR-200 modulates coelomocytes antibacterial activities and LPS priming via targeting Tollip in Apostichopus japonicus. Fish Shellfish Immunol. 2015;45(2):431-6.

46. Chen X, Whitney EM, Gao SY, Yang WW. Transcriptional profiling of Kruppellike factor 4 reveals a function in cell cycle regulation and epithelial differentiation. J Mol Biol. 2003;326(3):665-77.

47. Segre JA, Bauer C, Fuchs E. Klf4 is a transcription factor required for establishing the barrier function of the skin. Nat Genet. 1999;22(4):356-60.

48. Chen YC, Liao BK, Lu YF, Liu YH, Hsieh FC, Hwang PP, et al. Zebrafish Klf4 maintains the ionocyte progenitor population by regulating epidermal stem cell proliferation and lateral inhibition. PLoS Genet. 2019;15(4):e1008058.

49. Wong CK, Chan DK. Isolation of viable cell types from the gill epithelium of Japanese eel Anguilla japonica. Am J Phys. 1999;276(2):R363-72.

50. Sreedharan S, Shaik JH, Olszewski PK, Levine AS, Schioth HB, Fredriksson R. Glutamate, aspartate and nucleotide transporters in the SLC17 family form four main phylogenetic clusters: evolution and tissue expression. BMC Genomics. 2010;11:17.

51. Wiesenthal AA, Muller C, Harder K, Hildebrandt JP. Alanine, proline and urea are major organic osmolytes in the snail Theodoxus fluviatilis under hyperosmotic stress. J Exp Biol. 2019;222(Pt 3):jeb193557. 
52. Friedlander MR, Mackowiak SD, Li N, Chen W, Rajewsky N. miRDeep2 accurately identifies known and hundreds of novel microRNA genes in seven animal clades. Nucleic Acids Res. 2012;40(1):37-52.

53. Griffiths-Jones S, Grocock RJ, van Dongen S, Bateman A, Enright AJ. miRBase: microRNA sequences, targets and gene nomenclature. Nucleic Acids Res. 2006;34(Database issue):D140-4.

54. Love Ml, Huber W, Anders S. Moderated estimation of fold change and dispersion for RNA-seq data with DESeq2. Genome Biol. 2014;15(12):550

55. Wang SY, Lau K, Lai KP, Zhang JW, Tse AC, Li JW, et al. Hypoxia causes transgenerational impairments in reproduction of fish. Nat Commun. 2016;7: 12114.

56. Bray NL, Pimentel H, Melsted P, Pachter L. Near-optimal probabilistic RNAseq quantification. Nat Biotechnol. 2016;34(5):525-7.

57. Lai KP, Li JW, Gu J, Chan TF, Tse WK, Wong CK. Transcriptomic analysis reveals specific osmoregulatory adaptive responses in gill mitochondria-rich cells and pavement cells of the Japanese eel. BMC Genomics. 2015;16:1072.

58. Robinson MD, McCarthy DJ, Smyth GK. edgeR: a bioconductor package for differential expression analysis of digital gene expression data. Bioinformatics. 2010;26(1):139-40.

59. Enright AJ, John B, Gaul U, Tuschl T, Sander C, Marks DS. MicroRNA targets in drosophila. Genome Biol. 2003;5(1):R1.

60. Lai KP, Li JW, Tse AC, Chan TF, Wu RS. Hypoxia alters steroidogenesis in female marine medaka through miRNAs regulation. Aquat Toxicol. 2016;172:1-8.

61. Lambert NJ, Gu SG, Zahler AM. The conformation of microRNA seed regions in native microRNPs is prearranged for presentation to mRNA targets. Nucleic Acids Res. 2011:39(11):4827-35.

62. da Huang W, Sherman BT, Lempicki RA. Systematic and integrative analysis of large gene lists using DAVID bioinformatics resources. Nat Protoc. 2009; 4(1):44-57.

\section{Publisher's Note}

Springer Nature remains neutral with regard to jurisdictional claims in published maps and institutional affiliations.

Ready to submit your research? Choose BMC and benefit from:

- fast, convenient online submission

- thorough peer review by experienced researchers in your field

- rapid publication on acceptance

- support for research data, including large and complex data types

- gold Open Access which fosters wider collaboration and increased citations

- maximum visibility for your research: over $100 \mathrm{M}$ website views per year

At $\mathrm{BMC}$, research is always in progress.

Learn more biomedcentral.com/submissions 